\title{
PERANG YANG BENAR DALAM ISLAM
}

\author{
Abdul Basith Junaidy \\ UIN Sunan Ampel Surabaya | JI. A. Yani I I 7 Surabaya \\ basithjunaidy 7 I gmail.com
}

\begin{abstract}
This article discusses about true war in Islam. On various occasions, when the Qur'an obliged Muslims to fight, the Qur'an always requires that it should be carried out without transgressing behavior, according to appropriateness, accompanied by an attitude of forgiveness and seeking peace. Islam forbids attacking people who do not take part in wars such as children, women, elderly, widows, ascetics, priests or anyone who does not try or cannot fight Muslims. In every military operation, the Prophet always forbade his troops to injure people who did not join in the war or in vain to destroy property or plants. The Prophet actually ordered to treat those who were injured or feed those who were in need, including prisoners of war.
\end{abstract}

Keywords: War, jihad, qitâl, Islam.

Abstrak: Artikel ini membahas tentang perang yang benar dalam Islam. Pada berbagai kesempatan, ketika al-Qur'an mewajibkan umat Islam untuk berperang, al-Qur'an selalu mensyaratkan agar hal itu dilakukan tanpa perilaku melampaui batas, sesuai kepantasan disertai sikap memaafkan dan mencari perdamaian. Islam melarang penyerangan terhadap orang-orang yang tidak ikut perang seperti anak-anak, perempuan, lansia, janda, pertapa, pendeta atau siapa pun yang tidak berusaha atau tidak bisa memerangi umat Islam. Pada setiap operasi militer, Nabi saw selalu melarang pasukannya melukai orang-orang yang tidak ikut berperang atau secara sia-sia merusak harta atau tumbuhtumbuhan. Nabi saw justru memerintahkan untuk merawat mereka yang terluka atau memberi makan bagi yang membutuhkan, termasuk tawanan perang.

Kata Kunci: Perang, jihad, qitâl, Islam.

\section{Pendahuluan}

Perang dalam Islam seringkali diidentikkan dengan jihad. Islam dan jihad adalah dua kata yang seringkali tidak terpisahkan. Perang dalam Islam sering dimaknai dalam konteks perang suci 
membela agama, sedangkan jihad tidak selalu identik dengan perang. ${ }^{1}$

Tidak ada aspek dalam agama Islam, yang pada akhir-akhir ini mendapatkan sorotan paling tajam, baik di masyarakat maupun media massa dan media sosial, melebihi terorisme dan jihad. Seminar, diskusi, dan banyak kajian yang digelar untuk membahas tentang terorisme dan kekerasan dalam Islam. ${ }^{2}$

Umat Islam sendiri memahami terma jihad dengan beragam pandangan yang berbeda. Pernyataan dan perilaku sebagian muslim yang terbukti melakukan serangkaian tindakan terorisme di berbagai belahan dunia menjadikan konsep jihad makin membingungkan dan makin rumit. Jihad, khususnya sebagaimana terpotret di media massa di Barat, seringkali dikaitkan dengan ide perang suci terhadap kaum kafir yang disebarluaskan atas nama Tuhan dan dipandang sebagai tindakan intoleransi dalam beragama. Isu terorisme benar-benar telah mencoreng reputasi Islam sebagai agama damai. Semua ini terjadi karena adanya pemahaman yang buruk dan kurang tepat terhadap makna jihad yang sebenarnya dalam sumber-sumber hukum utama Islam. Atas dasar itu, kajian ini mencoba untuk menelusuri makna jihad dalam tataran etimologis dan tataran historis sepanjang sejarah umat Islam.

\section{Makna Jihad}

Jihad adalah prinsip utama dalam ajaran Islam. Istilah itu sendiri secara harfiah berarti "berusaha keras, tekun bekerja, berjuang dan dan mempertahankan". Dalam banyak hal, jihad berarti etika kerja yang kuat secara spiritual dan material di dalam Islam. Kesalehan, pengetahuan, kesehatan, keindahan dan keadilan tidak dimungkinkan tanpa jihad, yaitu tanpa kerja keras berkesinambungan dan tekun. Oleh karena itu, membersihkan diri

\footnotetext{
' Muh. Fajar Shodiq, Perlindungan Penduduk Sipil dan Etika Perang dalam Islam", Gema, Tahun XXVI/48/Februari 2014-Juni 2014, I440.

2 Ganjar Widhiyoga, "Normativitas Perang dalam Islam", Jurnal Politik Profetik, Volume 2 Nomor 2 Tahun 2013, 2.
} 
dari kesombongan dan kerendahan, menuntut ilmu, menyembuhkan orang yang sakit, memberi makan kaum papa, menegakkan kebenaran dan keadilan, bahkan dengan resiko pribadi yang besar, semuanya adalah bentuk jihad. ${ }^{3}$

Al-Qur'an menggunakan istilah jihad untuk merujuk pada tindak kerja keras untuk mewujudkan tujuan Tuhan di muka bumi ini, yang mencakup semua aktifitas yang disebut di atas. Nabi Muhammad saw berulangkali mengajarkan bahwa bentuk jihad terbesar adalah memerangi hasrat rendah manusia atau menyampaikan kebenaran di hadapan kekuasaan yang menindas dan menderita sebagai konsekwensi berbicara seperti itu. Dengan logika yang sama, berusaha sekuat tenaga dan bekerja keras dalam perang, asalkan perang tersebut adil dan baik, juga termasuk jihad. Logika serupa juga memberikan penekanan bahwa sepanjang tujuan atau maksudnya baik, perjuangan untuk mencapainya adalah juga jihad. Demikian pula, menentang penguasa yang tidak adil, bahkan jika dilakukan dengan kekerasan, bisa dipandang sebagai jihad. ${ }^{4}$

Menurut Alwi Shihab, dalam peristilahan al-Qur'an, jihad dibagi atas 2 kategori: Pertama adalah jihad fî sabîlillâh dan kedua jihad fillâh. Yang pertama dimaksudkan sebagai usaha sungguhsungguh dalam menempuh jalan Allah, termasuk di dalamnya pengorbanan harta dan nyawa. Dengan demikian, salah satu bentuk jihad dalam kategori ini adalah aksi yang melibatkan kemungkinan hilangnya nyawa seseorang dalam suatu konfrontasi fisik. Contoh nyata adalah berperang di jalan Allah swt. Pengorbanan para pahlawan bangsa dalam merebut dan mempertahankan kemerdekaan adalah salah satu bentuk jihad fî sabîlillâh. ${ }^{5}$

Sedangkan jihad fillâh atau usaha sungguh-sungguh (menghampiri Allah) adalah usaha untuk memperdalam aspek spiritual sehingga terjalin hubungan erat antara seseorang dengan

Khaled Abou el-Fadl, Selamatkan Islam dari Muslim Puritan, (Jakarta: Serambi, 2005), 265.

${ }^{4}$ Ibid., 267.

5 Alwi Shihab, Islam Inklusif, (Bandung: Mizan, 1997), 284. 
Allah swt. Usaha sungguh-sungguh ini diekspresikan melalui penundukan tendensi negatif yang bersarang dalam jiwa tiap manusia dan penyucian jiwa sebagai titik orientasi seluruh kegiatan. Kategori kedua ini sesuai dengan hadis Nabi saw yang popular adalah jihad dalam arti sebenarnya dan yang utama. Untuk memperjelas substansi jihad agar tidak diidentikkan dengan aksi mengangkat senjata, al-Qur'an membedakan antara konsep qitâl (interaksi bersenjata) dengan konsep jihad. Jihad menunjuk kepada suatu konsep yang lebih komprehensif, di mana salah satu sisinya adalah berjuang di jalan Allah swt melalui penggunaan senjata. ${ }^{6}$ Namun jihad dalam pengertian sempit ini (mengangkat senjata) oleh al-Qur' an dibatasi hanya diperbolehkan pada saat tertentu saja, khususnya dalam rangka mempertahankan diri (QS. al-Baqarah (2) :190-191). Agaknya pengertian sisi sempit ini telah secara keliru difahami dan dianggap sebagai ciri utama jihad yang menimbulkan kontroversi dan perbedaan pendapat. Akibatnya, isu jihad ini tidak saja menimbulkan antagonis antara cendekiawan muslim dan orientalis, akan tetapi juga telah mewarnai perselisihan pendapat antar-muslim. Dalam interaksi umat Islam dengan kelompok luar yang mengancam eksistensinya, para cendekiawan muslim dari masa ke masa berpendapat bahwa penggunaaan jihad dengan pengertiannya yang sempit dapat dibenarkan. ${ }^{7}$

Menurut al-Ashfahany, sebagaimana dikutip Muflikhatul Khairah, term jihad dalam al-Qur'an memiliki tiga pengertian; pertama, berjuang melawan musuh nyata yaitu orang kafir, kedua, berjuang melawan setan, dan ketiga, berjuang melawan nafsu. ${ }^{8}$

Secara literal dan umum, jihad berarti 'berusaha' atau 'berperang di jalan Allah. Semua muslim diperintahkan untuk berjihad. Istilah perang suci, yang banyak digunakan media Barat dan di kalangan sebagian muslim, hanyalah salah satu bentuk jihad.

\footnotetext{
${ }^{6}$ Ibid.

7 Ibid., 285.

8 Muflikhatul Khairah, "Jihad dan Hukum Perang dalam Islam", Jurnal al-Q anun, Volume I I Nomor 2 Desember 2008, 356.
} 
Namun perluasan makna ini bukan merupakan fokus utama bagi istilah yang sarat makna di sepanjang sejarah Islam ini. Meskipun ada sejumlah ekstremis garis keras di kalangan muslim yang menyerukan dan melakukan tindakan tercela di bawah panji jihad, namun mereka hanya mewakili minoritas kecil dalam tubuh umat Islam. Akibatnya, kita mengambil resiko menafsirkan tradisi agama yang lebih besar ini melalui kacamata perilaku kaum ekstremis yang sempit ini. Menurut pengakuan Charles Kimball, pengalaman 20 tahun belajar dan berinteraksi secara personal dengan kaum muslim, ia menyatakan tanpa ragu bahwa sebagian besar kaum muslim begitu ngeri dan muak dengan ekstremisme garis keras sebagaimana kebanyakan orang Kristen, Yahudi, Hindu, Budha dan orang-orang yang tidak mau mengidentifikasi kekerasan dengan agama manapun. ${ }^{9}$

Menurut Kimball, berdasar kutipannya pada artikel Zayed Yasin, pada tingkat paling dasar, jihad adalah satu perjuangan terus menerus agar menjadi orang yang baik dan bermoral, melakukan perbuatan baik untuk orang lain dan bagi kemaslahatan masyarakat. Suatu hadis Nabi terkenal menekankan makna ini berlawanan dengan konotasi militeristiknya. Dalam perjalanan pulang dari suatu pertempuran, Nabi Muhammad saw mengatakan kepada kaum muslim bahwa mereka baru kembali dari jihad kecil menuju jihad yang lebih besar. Perjuangan untuk mempertahankan Islam bukan tantangan terbesar. Jihad yang lebih besar adalah perjuangan batin untuk mengatasi nafsu egois dan dosa, kecenderungan kuat yang menghalang-halangi manusia melakukan hal-hal yang mereka yakini benar. ${ }^{10}$

Jihad menjadi sebuah simbol kuat bagi kesungguhan, kerja keras dan kesuksesan di dalam sejarah Islam. Sebagai simbol, jihad digunakan sebagai sarana untuk mewadahi antusiasme, emosi dan gairah yang meluap untuk berbagai tujuan, termasuk untuk berperang. Dalam perang, jika pertempurannya adalah antara

${ }^{9}$ Charles Kimball, Kala Agama Jadi Bencana, (Bandung: Mizan, 2003), 259.

${ }^{10}$ lbid., 260. 
muslim dan non muslim, maka seruan jihad dikumandangkan oleh penguasa. Akan tetapi jika tujuannya bersifat internal dalam negeri, seperti protes masyarakat, pemberontakan, penggalangan dana untuk membangun tempat ibadah dan sarana pendidikan atau menghimpun dana untuk mendirikan perpustakaan, maka seruan jihad biasanya dikeluarkan oleh ulama paling terkemuka yang sangat mumpuni dalam ilmu agama. Seruan jihad ini hanya akan menjadi panggilan yang dipatuhi manakala otoritas moral dan bobot persuasif yang dimiliki penguasa atau ulama tersebut sangat kuat di hati sanubari masyarakat. Bahkan ketika penguasa tertentu telah menerapkan wajib militer secara paksa, maka tiada pilihan lain bagi rakyat selain mengikuti seruan jihad tersebut. ${ }^{11}$

\section{Perang Suci atas Nama Tuhan dalam Tradisi Kristen}

Perang suci sama sekali tidak suci. Betapa pun mendalamnya rasa benci dan ketidakadilan yang dirasakan, perang suci bukan jawaban. Apa pun pembenaran keagamaan dikemukakan orang Kristen atau muslim di masa lalu , "perang suci" selalu membawa akibat mengerikan. Menghendaki suatu perang suci saat ini hanya berarti menyusuri suatu jalan buntu. Agama yang sehat tidak menyerukan perang, tetapi janji kedamaian dengan keadilan. Orang beriman kini harus mencari dengan sungguh-sungguh, dari tradisi agama masing-masing, suatu petunjuk dan penjelasan tentang jalan yang akan mengantarkan ke perdamaian dan keadilan. ${ }^{12}$

Ketika menyusuri perjalanan panjang hubungan kaum muslim dan kaum Kristen, didapati kenyataan bahwa masing-masing pengikutnya saling berperang karena alasan-alasan yang dinyatakan sebagai perang suci. Padahal kedua agama ini samasama mengklaim bahwa perdamaian merupakan inti agama mereka. Pada kedua agama ini, sudah terdaftar nama-nama tokoh yang mengorupsi inti agama dengan mengaitkannya pada perang.

\footnotetext{
I' Khaled Abou el-Fadl, Selamatkan Islam dari Muslim Puritan, 266.

12 Ibid., 264.
} 
Dalam sejarah Kristen terdata adanya 3 sikap dan pendekatan yang berbeda terhadap perang dan perdamaian yaitu pasifisme, doktrin perang adil (just war) dan perang Salib. Doktrin pasifisme menuntut komitmen yang kuat pada sikap anti kekerasan. Yesus menolak jubah militer yang tengah disiapkan orang-orang fanatik dan beberapa calon pengikutnya yang menuntutnya. Para pengikut Yesus pada 3 abad pertama adalah penganut paham pasifis. John Ferguson menulis sebuah catatan bahwa Kristen dan perang tidak sejalan. Orang Kristen diciptakan untuk perdamaian, Tuhan melarang pembunuhan, meskipun karena alasan yang adil, tanpa kecuali. Senjata orang Kristen adalah doa, keadilan dan penderitaan. ${ }^{13}$

Namun kemudian terjadi titik balik dari sikap tersebut yang dimulai sejak Konstantin dinobatkan sebagai Kaisar Imperium Romawi pada awal abad ke-4. Ia merasa mendapatkan kemenangan dalam suatu perang besar setelah sehari sebelumnya mendapatkan ilham tentang Salib Putih bertuliskan kata-kata Yunani "Pada tanda ini kamu akan menang". Ada yang menarik, setelah mengalami 2 gelombang penganiayaan terburuk dari pemerintah Romawi, agama Kristen tiba-tiba menjadi agama resmi Imperium Romawi. Perubahan dramatis itu terjadi selama 2 dasawarsa setelah Kaisar Konstantin melakukan konsolidasi kekuasaannya. Ketika agama Kristen berhubungan dengan kekuasaan negara, maka situasinya menjadi berubah. Ancaman atas keselamatan negara menjadi ancaman bagi gereja.

Pada abad ke-4, Ambrose mempelopori doktrin perang adil, dalam arti perang itu harus adil dan biarawan dan pendeta harus abstain dalam hal ini. Roland Bainton, sejarahwan terkemuka meringkas pendapat Augustinus tentang perang adil. ${ }^{14}$

"Tujuan perang harus adil yaitu memulihkan perdamaian...

Perang itu dianggap adil jika ia menuntut balas atas luka-luka, watak perang harus adil yaitu cinta Kristen. Cinta tidak melarang 
kekerasan yang bermanfaat karena perbaikan dikehendaki cinta itu sendiri...Perang harus dilakukan hanya di bawah otoritas penguasa....Perilaku perang harus adil. Iman harus dipertahankan bersama musuh. Tidak boleh ada kekerasan brutal, profanisasi tempat ibadah, perampokan, pembunuhan massal atau pembakaran. Dendam, kekejaman, pembalasan tidak diperkenankan, meskipun penyergapan diperbolehkan"

John Ferguson mencatat beberapa kriteria dasar yang harus dipenuhi dalam perang suci yaitu; (i) perang harus diumumkan oleh otoritas yang sah, (ii) ada alasannya, (iii) pihak yang sedang berperang harus memiliki niat baik, mengembangkan kebaikan atau menghindari keburukan, (iv) perang harus dilakukan dengan cara-cara yang tepat. Kadang-kadang kriteria tambahan ditemukan yaitu; (v) tindakan yang dilakukan harus melawan pihak yang bersalah, (vi) orang tidak bersalah tidak boleh menderita, (vii) perang harus dilakukan sebagai pilihan terakhir dan (viii) harus ada peluang kemenangan yang masuk akal. Dalam hal ini Ferguson hendak menunjukkan bahwa doktrin itu memiliki andil dalam mendukung orang-orang yang tengah memegang kekuasaan gereja atau kekuasaan duniawi karena kekerasan terhadap mereka, berdasarkan kriteria ini, adalah tidak adil. Tidak ada cara yang efektif untuk menentukan apakah perang itu adil atau tidak, karena pada dasarnya perang itu adil jika tokoh yang berwenang menyatakan demikian. Dan doktrin ini juga tidak memiliki keterkaitan yang nyata dengan iman Kristen, justru argumenargumen filsafat Yunani dan hukum Romawi yang mendominasi doktrin perang adil ini. Doktrin ini menyatakan bahwa kaum pagan, pelaku bid'ah dan orang kafir adalah orang yang benar-benar melawan hukum Tuhan. Hukum konvensional yang diakui fleksibel ini tidak secara otomatis melindungi masyarakat yang telah diidentifikasi sebagai musuh gereja. ${ }^{15}$

Tipe respon ketiga kaum Kristen terhadap perang dan perdamaian adalah perang salib dengan menggabungkan perang adil 
dan tradisi pasifis, yang terus berlangsung. Perang salib bermula pada Maret 1095 pada saat Alexius meminta bantuan kepada Paus Urbanus II untuk melawan orang-orang Turki yang berada dalam jarak serangan dari ibu Kota Bizantium, Konstantinopel. Pada akhir November tahun tersebut Paus menyampaikan khutbah yang berapi api di kota Clermont Prancis, yang menyerukan bangsa Frank agar bergerak ke Timur dengan 2 tujuan yaitu membantu orang-orang Bizantium mengusir orang-orang Turki dan membebaskam Jerussalem dari kekuasaan muslim. Seruan tersebut mendapatkan respon yang kuat dengan teriakan jemaat berulangulang "dengan kehendak Tuhan!". Beberapa bulan kemudian pesan tersebut tersebar melalui berbagai khutbah, surat-surat Paus dan dari mulut ke mulut di Prancis, Italia dan beberapa wilayah Jerman. Alih-alih perang adil yang dideklarasikan raja, perang Ssalib justru dihasut oleh gereja. Baik Alexius maupun Urbanus tidak dapat mengantisipasi respon massa. Sebelum keberangkatan yang dijadwalkan pada musim panas tahun 1096, banyak orang miskin memutuskan untuk memenuhi panggilan itu tanpa menundanunda. Dengan persiapan minim atau perbekalan yang tidak memadai, banyak orang mulai bergerak menuju Jerussalem di bawah bendera salib.

Sejak awal "perang salib para petani" ini, semangat dan niat yang benar berubah menjadi tindakan yang mengerikan. Sebelum meninggalkan Jerman, beberapa prajurit salib membunuh banyak orang Yahudi, yang dianggap sebagai musuh Kristus. Suatu film dokumenter berdurasi 4 jam yang diproduksi untuk British Broadcasting Corporation (BBC) melacak kekerasan luar biasa yang dilakukan oleh "orang-orang fanatik biadab yang yakin mereka sedang menjalankan misi suci Tuhan". Christopher Tyerman dari Oxford University melihat bagaimana pendekatan baru terhadap perang ini menggambarkan suatu pembalikan sikap yang sangat dramatis :"Kalau pada tahun 1066, para prajurit yang bertempur di Hastung harus melakukan penebusan dosa atas pembantaian yang 
mereka lakukan, maka pada perang salib pertama, pembunuhan itu sendiri sebagai tindakan penebusan dosa. ${ }^{16}$

Perang salib pertama berhasil menguasai Jerussalem yang saat itu di bawah kekuasaan orang Mesir. Kota ini berpenduduk 100 ribu orang yang di dalamnya orang-orang Yahudi, Kristen dan muslim hidup bersama dengan baik dalam lingkungan multikultural. Namun, pada 15 Juli 1099, para prajurit salib meruntuhkan pertahanan kota Jerussalem dan mulai melakukan pembantaian tanpa ampun. Para tentara salib membakar Sinagoge Agung, tempat orang Yahudi berkumpul mencari perlindungan dan membakar orang-orang Yahudi itu hidup-hidup. Para tentara salib juga mengobrak-abrik Temple Mount, tempat ribuan muslim berkumpul melakukan shalat Jumat. Ketika berlari ke masjid AlAqsha, orang-orang Islam membayar banyak uang tebusan sebagai jaminan keamanan mereka, namun hari berikutnya mereka semua dibunuh. ${ }^{17}$

Gerak maju menuju penguasaan atas kota Jerussalem mengawali serangkaian perang salib tandingan yang terus berlanjut selama berabad-abad. Selain inisiatif terencana diarahkan pada tanah suci, berbagai perang salib yang lebih kecil juga terjadi di tempat lain, seperti pertikaian dengan kaum muslim yang berlangsung di sejumlah tempat, seperti Spanyol, Eropa Tengah hingga ujung timur kawasan Mediterania. Kepemimpinan Gereja Roma terlibat secara intensif dalam proses dinamis ini, dengan mengatur dan memotivasi para pejuang salib dengan janji pengampunan dosa. Sejarah yang kompleks ini menunjukkan bahwa faktor ekonomi dan politik yang bersinggungan dengan motivasi keagamaan sedemikian kompleks sehinga tidak dapat dianalisis dengan mudah. ${ }^{18}$

16 lbid., 244-245.

17 lbid., 245.

18 lbid., 247. 


\section{Perang Suci atas Nama Tuhan dalam Islam}

Jika dikaji secara mendalam, sebenarnya tradisi teologis Islam tidak memiliki gagasan berkaitan dengan perang suci sebagaimana dalam tradisi Kristen-Katholik. Islam tidak memiliki semacam institusi otoritas kependetaan yang bisa membuat keputusan mengenai status kesucian sebuah perang. Dalam tradisi Kristen, terdapat sebuah institusi yang bisa secara menentukan dan konsklusif menyatakan sekelompok pasukan tertentu berstatus tentara salib atau peziarah dalam tentara Tuhan dan menjamin penebusan dosa bagi prajurit ini. Sedangkan dalam ajaran Islam, tak seorang pun, bahkan khalifah atau ahli hukum yang paling tinggi kedudukannya pun, yang memiliki kekuasaan hebat untuk menjamin penebusan atau merumuskan suatu operasi militer dengan status suci atau ilahiah. Jihad semata-mata berarti berusaha keras atau perjuangan dalam rangka suatu tujuan yang benar. ${ }^{19}$

Perang suci (dalam bahasa Arab: al-harb al-muqaddasah) bukan ungkapan yang dipakai al-Qur'an atau para teolog muslim. Dalam teologi Islam, perang itu tak pernah suci, baik sah atau tidak. Jika perang tersebut sah, maka mereka yang terbunuh di dalam peperangan dipandang sebagai syuhadâ' (martir). Akan tetapi penentuan status syahid ada pada wilayah eksklusif Tuhan; hanya Tuhan yang bisa menilai niat seseorang dan ketulusan niatnya, dan akhirnya Tuhan lah yang berhak menentukan apakah mereka layak menjadi syuhadâ' atau tidak. Tak satu pun teks dalam al-Qur'an yang mengakui adanya gagasan tentang perang yang tidak terbatas dan tidak mempertimbangkan adanya fakta sederhana tentang identitas muslim yang agresif dalam menegakkan keadilannya sendiri. Dengan kata lain, al-Qur'an mempertimbangkan adanya kemungkinan bahwa prajurit muslim bisa jadi merupakan kelompok yang bersalah dalam konflik yang sedang terjadi.20 Menurut al-Qur'an, perang boleh jadi diperlukan bahkan

\footnotetext{
${ }^{19}$ Khaled Abou el-Fadl, Selamatkan Islam dari Muslim Puritan, 267.

${ }^{20}$ Khaled Abou el-Fadl, Cita dan Fakta Toleransi Islam: Puritanisme versus Pluralisme, (Bandung: Arasy Mizan, 2003), 34-35.
} 
diwajibkan pada situasi mendesak tertentu, akan tetapi perang tidak pernah menjadi kebaikan moral dan etis. ${ }^{21}$

Lebih dari itu, meskipun al-Qur'an menekankan bahwa umat Islam musti melawan orang-orang yang memerangi mereka, alQur'an juga menegaskan bahwa umat muslim tidak boleh melampaui batas. Pelampauan batas merupakan istilah yang ambigu, tetapi dalam beberapa kesempatan al-Qur'an mengisyaratkan bahwa agar tidak melampaui batas, umat muslim harus dibatasi oleh syarat-syarat kepantasan, meski ketika penyebabnya adalah keadilan. Misalnya, al-Qur'an menyatakan bahwa hukum qishâsh berlaku. Dalam Aal-Qur'an dinyatakan:

"Barangsiapa menyerang kamu, maka seranglah ia, seimbang dengan serangan terhadapnya. Bertakwalah kepada Allah dan ketahuilah bahwa Allah beserta orang-orang yang bertakwa". ${ }^{22}$

Al-Qur'an tidak menggunakan istilah jihad untuk merujuk pada perang atau pertempuran. Sebaliknya, al-Qur'an menggunakan istilah qitâl untuk merujuk pada perang atau pertempuran. Ketika al-Qur'an menyebut jihad secara mutlak dan tak terbatas, maka hal yang serupa tidak berlaku pada kata qitâl. Jihad itu selalu baik, sebab ia mirip dengan etika kerja Protestan: kerja keras menuju tujuan yang baik. Akan tetapi, qitâl (perang/pertempuran) adalah sesuatu yang berbeda sama sekali. Setiap acuan pada qitâl di dalam al-Qur'an selalu dibatasi oleh kondisi kondisi tertentu. Akan tetapi desakan pada jihad, seperti acuan pada kebenaran dan keadilan, selalu bersifat mutlak dan tidak bersyarat. Pada berbagai kesempatan, ketika al-Qur'an mendesak umat Islam untuk berperang, al-Qur'an selalu mensyaratkan dan menuntut mereka agar hal itu dilakukan tanpa perilaku melampaui batas disertai sikap memaafkan dan mencari perdamaian. Walau pun ajaran dan nilai tersebut mudah ditemukan di beberapa tempat dalam al-Qur'an, anehnya realitas tekstual ini cenderung dilupakan oleh banyak sarjana muslim dan non-muslim

\footnotetext{
${ }^{21}$ Khaled Abou el-Fadl, Selamatkan Islam dari Muslim Puritan, 267.

22 AlQur'an (2): 194.
} 
yang mempelajari al-Qur'an. Meski demikian, tidak diperselisihkan bahwa al-Qur'an tidak pernah mendukung pilihan militer tanpa mensyaratkan pilihan itu dengan beberapa cara yang signifikan. ${ }^{23}$

Walaupun al-Qur'an tidak membenarkan gagasan tentang perang yang tak terbatas atau konsep perang suci, keadaan historis para ahli hukum abad pertengahan, yang menulis khususnya pada abad ke-9 dan ke-10 sangat mempengaruhi cara para ahli hukum ini membaca dan menafsirkan al-Qur'an. Pada periode sejarah ini, bangsa-bangsa dan dinasti-dinasti, dengan tiadanya pakta perdamaian, memandang diri mereka berada dalam situasi perang terus menerus dengan semua yang lain. Di abad pertengahan, menaklukkan dan mengalahkan pihak yang lemah adalah bagian dari kebiasaan dan praktik bangsa dan kerajaan yang diterima.

Berdasarkan preseden yang ditunjukkan Nabi Muhammad saw, para ahli hukum Islam klasik menegaskan bahwa orang-orang yang tidak ikut perang seperti anak-anak, perempuan, lansia, janda, pertapa, pendeta atau siapa pun yang tidak berusaha atau tidak bisa memerangi umat Islam tidak bisa diganggu gugat dan tidak bisa dijadikan target, bahkan ketika berlangsung peperangan terus menerus. Pada setiap operasi militer, Nabi saw biasa memerintahkan pasukannya untuk tidak melukai orang-orang yang tidak ikut berperang atau secara sia-sia merusak harta atau tumbuh-tumbuhan. Nabi saw justru memerintahkan untuk merawat mereka yang terluka atau memberi makan bagi yang membutuhkan, termasuk tawanan perang. Dalam sebuah riwayat yang sangat terkenal, diceritakan secara panjang lebar bahwa sesudah perang, setelah menemukan mayat seorang perempuan, Nabi saw sangat kesal, kecewa dan memarahi pasukannya karena membunuh seseorang yang tidak ikut berperang. ${ }^{24}$

Islam mengajarkan bahwa salâm (kedamaian dan ketentraman) adalah syarat moral utama yang berulang-ulang ditekankan, baik dalam praktik-praktik ritual seperti salat dan dalam semua praktik

${ }^{23}$ Khaled Abou el-Fadl, Selamatkan Islam dari Muslim Puritan, 268.

${ }^{24}$ Ibid., 275. 
sosial Islam seperti saling mengucapkan salam di antara manusia. Dalam diskursus al-Qur'an dan teologi Islam, salâm atau kemampuan untuk hidup dalam kondisi damai dan tentram dipandang sebagai anugerah Tuhan yang amat besar, yang harus dihargai dan dicari oleh setiap muslim. Risalah-risalah teologis klasik yang meringkaskan sifat-sifat dasar Islam yang paling murni sering menyatakan bahwa Islam tidak hanya iman ketundukan, tetapi juga iman kedamaian ${ }^{25}$.

Akan tetapi menurut al-Qur'an, supaya lahir kondisi damai, umat Islam mesti secara aktif memupuk sikap memaafkan dan saling mengasihi. Oleh karena itu, al-Qur'an sangat keras mengingatkan umat Islam untuk tidak menciptakan kondisi yang dapat memicu balas dendam atau kebencian dengan satu atau lain kelompok dengan cara menusuk atau melukai hati mereka. Inilah sebabnya al-Qur'an memerintahkan umat Islam agar ketidakadilan yang dilakukan orang lain seyogyanya tidak dibiarkan mempengaruhi sikap muslim terhadap kewajiban moral mereka untuk mendorong pemaafan dan kasih sayang. Hal itu ditekankan berulang-ulang dalam al-Qur'an.26

Banyak ahli hukum klasik yang berpendapat bahwa kaum non-muslim tidak boleh diperangi kecuali jika mereka mengancam kaum muslim. Jika kaum non-Muslim ingin damai, maka kaum muslim mesti berusaha mewujudkan kedamaian tersebut. Wacana ini sebagian diinspirasi oleh perintah al-Qur'an tentang perdamaian. Al-Qur'an menyatakan bahwa Tuhan tidak melarang umat Islam untuk berdamai dengan mereka yang tidak memusuhi kaum muslim, tetapi Tuhan melarang kaum muslim berdamai dengan mereka yang telah mengusir kaum muslim dari rumahrumah mereka dan terus mengusir mereka. ${ }^{27}$

Pada bagian lain, al-Qur'an mengungkapkan perintah yang tegas mengenai perdamaian dengan menyatakan:"Jika mereka condong

\footnotetext{
25 Ibid., 280.

26 lbid.

${ }^{27}$ Al-Qur'an, QS. Al-Mumtahanah (60): 9.
} 
pada perdamaian, maka condonglah kepadanya dan bertawakkallah kepada Allah". ${ }^{28}$ Selain itu, al-Qur'an memerintahkan kepada umat Islam untuk tidak congkak dengan memalingkan muka dari orang-orang kafir yang ingin berdamai dengan mereka dan mengingatkan kepada kaum muslim. Dalam hal ini, al-Qur'an menyatakan:

Kalau Allah menghendaki kamu (muslim), tentu Dia akan memberikan kekuasaan kepada orang-orang kafir terhadap kamu (muslim), lalu mereka akan memerangimu (muslim). Tetapi jika mereka (orang-orang kafir) membiarkan kamu dan tidak memerangimu, dan malah mengemukakan perdamaian kepadamu, ketahuilah bahwa Allah tidak memberi izin kepadamu (untuk memerangi mereka). ${ }^{29}$

Diskusi tentang perdamaian ini tidak akan ada artinya jika kaum muslim selalu berada dalam kondisi perang melawan orangorang beriman dan jika orang-orang beriman tidak menjadi musuh abadi dan selalu menjadi sasaran yang sah. ${ }^{30}$

\section{Etika Perang dalam Islam}

Dalam Islam, ketika perang sudah tidak dapat dihindarkan, maka ada beberapa etika dan kaidah harus dipenuhi agar perang bisa berlangsung secara benar. Sejumlah kaidah yang menjadi pegangan tentara Islam dalam perang tidak hanya berdasarkan prinsip moral-etis Islam secara umum, akan tetapi juga merupakan aturan syariat yang diajarkan di dalam al-Qur'an dan sunnah. Para pelanggarnya tidak saja mendapat hukuman dari komandan mereka di dunia ini, tetapi mereka juga akan mendapatkan hukuman di akhirat nanti, karena dianggap melanggar ketetapan hukum Islam yang terdapat dalam al-Qur'an dan as-Sunnah.

Di antara kaidah-kaidah syariat yang paling penting dalam mengatur tentara Islam dalam perang adalah:

1. Pembatasan perang hanya pada para komandan musuh dan para kombatan saja

${ }^{28} \mathrm{Al}$-Qur'an, QS. Al-Anfal (8): 61.

${ }^{29}$ Al-Qur'an, QS. Al-Nisa (4): 90 dan 94.

${ }^{30}$ Khaled Abou el-Fadl, Cita dan Fakta Toleransi Islam, 36. 
Hal ini sesuai dengan hadis Nabi Muhammad saw ketika beliau berwasiat kepada Zaid bin Harisah saat hendak berangkat ke perang Mu'tah:

"Kalian jangan membunuh anak laki-laki, wanita, orang tua, lansia dan orang yang beribadah di biaranya"

Rasulullah saw berwasiat agar tidak menyerang serdadu yang sedang luka dalam perang, sebagaimana sabda Nabi saw:

"Jangan berperang dengan serdadu yang luka karena sebagian tubuhnya bukan miliknya".

Demikian juga tidak boleh menyakiti para petani sawah dan anak-anak, sebagaimana sabda Nabi saw:

"Jangan kamu bunuh anak-anak dan para petani".

Yang dimaksud anak-anak di sini adalah anak laki-laki dan petani adalah para pekerja yang membajak bumi dan menanamnya. Adapun kepada para wanita, Rasulullah saw melarang diperangi kecuali ia membawa senjata dan berhadapan dengan kaum muslim. Suatu ketika Rasulullah saw melihat mayat perempuan musyrik, maka beliau mengizinkan untuk membunuhnya, "Perempuan ini tidak apa apa untuk diperangi" ${ }^{31}$

2. Terjun ke medan perang dengan jiwa humanis

Tidak dibolehkan berperang kecuali karena ada alasan yang dibenarkan oleh syariat Islam. Dalam Al-Qur'an Allah swt berfirman:

"Dan janganlah kalian membunuh jiwa yang diharamkan Allah swt melainkan dengan suatu (sebab) yang benar. Demikian itu yang diperintahkan oleh Rabb kepada kalian supaya kalian memahami. ${ }^{32}$

Pembunuhan yang syar'i harus mengandung nilai kemanusiaan dan sesuai dengan hadis Nabi saw, "Jika kalian menyembelih, maka baguskanlah sembelihanmu". Hadis ini melarang penyiksaan secara tegas. Hadis lain menyatatakan, "Saya adalah Nabi yang menghunus pedang dan nabi Penyayang". Hal itu menjelaskan tentang perlakuan yang seharusnya

${ }^{31}$ Ameur Zemmali, editor, Islam dan Hukum Humaniter Internasional, (Bandung: Mizan, 20 I2), 294.

${ }^{32}$ Al-Qur'an, QS. Al-An'am (6): I5I . 
terhadap tubuh korban dan juga penghormatan pada kemuliaan mayat dan kemanusiaan manusia, sebagaimana sabda Nabi saw, "Waspadalah dan jadikanlah pelajaran meski hanya kepada anjing galak". Menurut pendapat mayoritas ulama, pembakaran mayat dilarang oleh Islam karena hal itu merupakan tradisi kaum pagan. Namun hal itu diperkenankan jika keadaan memaksa dan demi kemaslahatan umum, misalnya khawatir tersebarnya wabah penyakit tha'un (penyakit sampar). Secara umum, manusia wajib dihormati, karena jiwa manusia, sebagaimana dikatakan Fachrurrazi adalah yang paling mulia di alam semesta ini, pun demikian dengan fisiknya". 33

3. Mencegah perampasan yang biasa berlaku dalam perang jahiliyah

Rasulullah saw juga melarang tindakan perampasan harta manusia. Diriwayatkan dari seorang laki-laki Anshar, "Ketika kami dalam perjalanan bersama Rasulullah saw, ada manusia yang butuh sekali dengan kambing, maka mereka merampoknya, maka periuk kami pun mendidih dan tiba-tiba Rasulullah saw datang dan membalikkan periuk dengan lengannya, dan beliau melumuri daging itu dengan tanah dan berkata, "Perampasan itu tidak lebih halal dari mayat". Di sini perampasan harus dibedakan dari ghanimah, yaitu harta pampasan perang. Sebab ghanimah itu halal sebagaimana dijelaskan oleh dalil-dalil alQur'an dan sunnah. ${ }^{34}$

4. Melarang berkhianat

Larangan berkhianat berlaku bahkan dalam keadaan ketidakjelasan niat jahat musuh. Dalam hadis, Nabi saw melarang berkhianat dan lari dari medan perang, sebagaimana sabda beliau saw:

"Berangkatlah di jalan Allah dengan menyebut nama-Nya, berperanglah menghadai musuh-musuh Allah saw, jangan melampaui batas, jangan berkhianat, jangan memutilasi dan jangan membunuh anak-anak".

${ }^{33}$ Ameur Zemmali, Islam dan Hukum Humaniter Internasional, 295.

${ }^{34}$ Ibid., 296. 
Islam melarang membunuh musuh yang melarikan diri dari pasukannya dan tidak memperdayainya dengan menyatakan bahwa ia aman, dan setelah ia mendekat, lalu dibunuh. Kaidah-kaidah syariat Islam dalam keadaan aman membolehkan seorang prajurit muslim memberi keamanan bagi seorang atau sekelompok prajurit musuh. Bila hal itu dilakukan, maka orang kafir tersebut dijamin keamanan dan berada dalam lindungan orang-orang muslim. Setelah itu, ia tidak boleh dikhianati dan ditakut-takuti untuk dibunuh. Siapa pun muslim yang melakukan hal tersebut, maka dia adalah pembunuh yang wajib dijatuhi hukuman qishâsh (mati). ${ }^{35}$

Berkhianat harus dibedakan dari siasat perang. Pengkhianatan dilarang dalam perang, sedangkan siasat untuk mengalahkan musuh diperkenankan. Imam Nawawi mengatakan bahwa para ulama sepakat tentang kebolehan melakukan siasat terhadap orang-orang kafir jika memungkinkan. Taktik dan siasat pengelabuhan dalam peperangan tidak dilarang baik dalam Islam dan hukum internasional positif. Hal ini sesuai sabda Rasulullah saw: "Perang adalah siasat". Maksudnya tidak termasuk kebejatan moral untuk mengelabuhi musuh dengan taktik dan siasat. ${ }^{36}$ Rasulullah saw memerintahkan Nu'aim bin Mas'ud yang sudah masuk Islam agar tetap merahasiakan keislamannya agar dia secara bebas bisa menciptakan keraguan antara Kaum Quraish dan Bani Quraizhah yang sedang mengepung kota Mandinah pada saat perang Khandaq sebagai salah satu bentuk siasat. ${ }^{37}$

5. Melarang menghancurkan dan merusak harta benda

Syariat Islam melarang pengrusakan selama perang berlangsung. Atas dasar itu, Islam melarang memotong pohon yang berbuah, pembakaran pohon kurma dan penyembelihan kambing musuh, sapi dan lain-lain. Namun hal itu dibolehkan

\footnotetext{
35 Ibid., | 43.

36 Ibid.

${ }^{37}$ lbid., 410.
} 
hanya dalam keadaan darurat dalam rangka melemahkan musuh dan mengalahkannya. ${ }^{38}$ Namun dalam kondisi tertentu, para ulama membolehkan keluar dari prinsip tersebut, termasuk membolehkan menyembelih anjing dan binatang berbahaya lainnya serta binatang yang dapat dikonsumsi. ${ }^{39}$

6. Memberikan rasa aman kepada pihak yang meminta

Jika perang Eropa sampai awal abad ke-20 belum mengenal kewajiban memberikan rasa aman kepada tentara musuh, di mana para negosiator di konferensi Den Haaq tahun 1899 memaksakan pemuatan "Peraturan Penghormatan Hukum dan Kebiasaan Perang di Darat" yang melarang perlindungan pemimpin pasukan perang untuk mengumumkan penolakan penerimaan rasa aman, maka Islam sejak awal kemunculannya di abad ke-8 telah mengenal dan mempraktikkannya ${ }^{40}$ berdasarkan firman Allah saw:

"Dan jika seorang di antara orang-orang musyrikin itu meminta perlindungan kepadamu, maka lindungilah ia supaya ia sempat mendengar firman Allah saw, kemudian antarkanlah ia ke tempat yang aman baginya. Demikian itu karena mereka kaum yang tidak mengetahui." 41

Islam juga melarang mengarahkan serangan kepada musuh yang tidak berdaya. Saat musuh menyerah atau sudah lemah, pasukan muslim harus menghentikan aktifitas perang seperti larangan penganiayaan dengan tujuan mencegah pembunuhan terhadap para korban luka. ${ }^{42}$

7. Menghentikan peperangan jika pihak musuh menghentikannnya

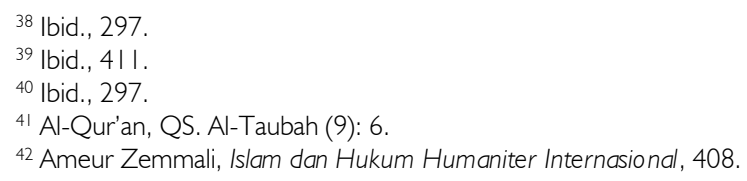

${ }^{42}$ Ameur Zemmali, Islam dan Hukum Humaniter Internasional, 408. 
Tujuan perang dalam Islam adalah demi terciptanya perdamaian dan toleransi. Perdamaian adalah hal yang fundamental dalam Islam. ${ }^{43}$

Dalam pandangan Islam, perang bukanlah tujuan utama melainkan jalan untuk membela kebenaran dan menghancurkan kebatilan. Karena itu, dilarang melanjutkan peperangan jika pihak musuh menghentikannya, sesuai dengan firman Allah saw: "Dan jika mereka condong kepada perdamaian, maka condonglah kepadanya dan bertawakkallah kepada Allah saw. Dialah yang Maha Mendengar lagi Maha Mengetahui". ${ }^{44}$

Tetapi, ada ahli fiqih yang membolehkan komandan untuk memerangi pasukan musuh jika mundurnya pasukan musuh merupakan salah satu bentuk taktik pengelabuhan militer dan bukan untuk menyerahkan diri dan ingin berdamai. Karena pada dasarnya, permohonan perdamaian dibuktikan dengan menghilangkan sebab-sebab terjadinya peperangan atau paling tidak ada kesediaan untuk menghilangkannya. ${ }^{45}$

8. Menguburkan korban perang yang meninggal

Rasulullah saw memerintahkan para sahabat untuk menguburkan korban yang meninggal dan mengabaikannya untuk mencegah penghinaan terhadapnya. Beliau bersabda, "Jika kalian membunuh, maka bunuhlah dengan sebaik-baiknya", dan memerintahkan mereka untuk mengubur jasad para korban perang Badar yang merupakan pertama melawan orang-orang musyrik, agar hal tersebut diikuti di kemudian hari ${ }^{46}$.

\section{Tujuan Perang dalam Islam}

Al-Qur'an banyak menerangkan tentang peperangan yang sangat dibenci manusia dan memerintahkan mereka untuk menundanya hingga menemui ajal. Akan tetapi kehidupan bagi

\footnotetext{
${ }^{43}$ Husni Fithriyawan, "Jihad dalam perspektif Muhammad Fethullah Gulen, al-finayah, Volume 3 Nomor I Juni 2017, 238.

${ }^{44} \mathrm{Al}$-Qur'an, QS. Al-Anfal (8): 61.

${ }^{45}$ Ameur Zemmali, Islam dan Hukum Humaniter Internasional, 298

${ }^{46}$ Ibid., 408.
} 
manusia dalam konsep al-Qur'an tidak mungkin tanpa tujuan luhur yang harus dicapai. Orang muslim memiliki kewajiban untuk menyebarkan dakwah dan memegang amanah, meskipun hidupnya memiliki nilai yang besar, akan tetapi akan menjadi hina jika kehormatannya terancam, atau jika diabaikan disebabkan kesempitan dan siksaan. Allah adalah Sang Maha Pemberi kehidupan, maka jika Dia meminta kita untuk mendermabaktikan diri kita di jalan-Nya, maka tidak seyogyanya kita kikir terhadapNya, karena "kebenaran dan tujuan" yang membolehkan mengorbankan jiwa, berkaitan dengan menjaga kehidupan yang mulia bagi manusia sendiri.

Peperangan yang disyariatkan dalam Islam diistilahkan dengan 'jihad'. Jihad secara istilah adalah mengorbankan tenaga dan mengerahkan kekuatan untuk berperang di jalan Allah dengan jiwa, raga, harta benda dan perkataan. Jihad telah disyariatkan untuk meninggikan kalimat Allah, menjunjung tinggi agama-Nya dan mencegah siksaan orang-orang musyrik serta untuk melapangkan jalan berdakwah di jalan-Nya agar sampai kepadaNya dan memisahkannya untuk perdamaian hingga Allah menunjukkan agama-Nya, karena semua agama hanya milik Allah swt. Tujuan berjihad dalam Islam, sebagaimana diriwayatkan oleh sebagian sahabat Rasulullah saw, adalah untuk mengeluarkan manusia dari kesempitan dunia menuju kelapangan dunia-akhirat dan dari penyembahan manusia kepada menyembah Allah swt Yang Maha Esa.

Islam secara naluri merupakan dakwah luhur yang bertujuan menuntun manusia kepada kebaikan dan mengeluarkan mereka dari kesusahan yang muncul dari kesesatan yang membelenggunya agar menatap seluruh dunia dan melihat ciptaan Allah swt, serta mengetahui apa yang menunggu mereka di alam akherat ${ }^{47}$.

Islam memiliki tujuan luhur yang berkaitan dengan kemajuan manusia dan tingginya kepentingan mereka. Rasulullah saw 
ditugaskan untuk menyampaikan dakwah kepada seluruh umat manusia tanpa mengabaikan seorang atau umat yang tidak sampai dakwah kepada mereka. Dakwah merupakan risalah langit yang diturunkan ke bumi. Allah memilih untuk risalah tersebut kepada utusan-Nya yang mulia, Rasulullah saw. Oleh karena itu, risalah harus dilaksanakan sebaik-baiknya. Beliau berdakwah kepada penduduk Mekkah selama 13 tahun dan menghadapi berbagai siksaan dan penganiayaan bersama para pengikutnya. Kaum Quraish selalu berupaya untuk membunuh Rasulullah saw dan merintangi dakwahnya serta melarang setiap individu dengan berbagai cara untuk memeluknya. Untuk itu, Nabi saw dan para pengikutnya harus berjihad hingga terbuka jalan dakwah agar manusia dapat sampai kepada kemudahan dan tanpa rintangan. Di Madinah, Rasulullah saw membentuk masyarakat politik dan membangun negara Islam dari satu sisi dan mempersiapkan kekuatan besar yang dapat menjamin dakwah dan kotanya tersebut dari berbagai perlawanan yang menantinya dan agar meneruskan fungsi menyampaikan dan menebarkan dakwahnya.

Jihad dalam rangka membuka jalan dakwah memiliki paling tidak 3 motif yaitu:

1. Melindungi kebebasan dalam beragama.

Termasuk realitas yang membedakan antara dakwah Islam dengan dakwah lain sebelumnya adalah sifatnya yang universal. Karena itu, risalah Islam muncul untuk disampaikan kepada seluruh umat manusia. Ketika bangsa-bangsa mengetahui hakekat risalah tersebut, maka tidak diragukan lagi pasti mereka akan beriman kepadanya, karena itu sesuai dengan fitrah Allah yang diciptakan untuk manusia dan jihad telah disyariatkan untuk mewujudkan tujuan tersebut. Dakwah Islam tidak menimbulkan pemaksaan bagi orang-orang non muslim untuk masuk agama Islam, akan tetapi menumbuhkan penjelasan tentang hukum-hukum perundang-undangan bagi mereka, mewujudkan kebebasan berkeyakinan di depan mereka jika mereka hendak masuk Islam, tanpa menjumpai halangan yang 
merintangi mereka. Itu tidak akan berubah kecuali jika dakwah berdiri dengan kokoh di depan kekuasaan negara-negara yang ditaklukkan dengan pemahaman yang ditempatkan di pusat kekuatan yang menjadikan orang-orang serius berfikir tentang keyakinan mereka dan terbebas dari kegagalan berhubungan dengan keyakinan-keyakinan mereka yang terlepas dari kelahirannya. Oleh karena itu, para kombatan muslim tidak akan ke suatu medan tempur kecuali disertai para muballigh dan penghafal al-Qur'an. ${ }^{48}$

Dengan demikian, tujuan utama peperangan dalam Islam adalah menyebarkan akidah Islam melalui jaminan kebebasan cara berfikir bagi seluruh individu hingga pada akhirnya mereka menerima cara berfikir apa saja yang masuk kepada mereka. Jaminan kebebasan cara berfikir masuk ke dalam tujuan tersebut dan juga beribadah bagi non-muslim. Atas dasar itu, Islam memberikan kekuatan-kekuatan yang baik untuk menentang kekuatan-kekuatan yang buruk, dan melindungi cara-cara berfikir manusia, dan tempat-tempat beribadah di mana asma Allah diagungkan di dalamnya agar tidak dihancurkan dan diluluhlantakkan. Semua ini merupakan peperangan di jalan Allah dalam rangka mempertahankan kebebasan berakidah. Namun peperangan tidak disyariatkan dalam keadaan tersebut selama tidak terdesak untuk mempertahankan Islam atau melindungii agama atau untuk mewujudkan kebebasan berakidah secara umum. Pada prinsipnya, membawa senjata bukan sarana berjihad, akan tetapi sarana pokok berjihad adalah dengan hikmah dan pengajaran yang baik. ${ }^{49}$

2. Bertahan melawan musuh

Semua undang-undang membolehkan setiap individu atau negara yang terzalimi untuk menolak kezaliman tersebut. Berdasarkan ayat-ayat al-Qur'an disimpulkan bahwa dalam rangka mempertahkan diri ada beberapa syarat yang harus 
dipenuhi yaitu: Pertama, syarat keharusan, yakni keharusan mempertahankan diri dari kezaliman musuh. Artinya janganlah bergegas untuk melakukan perlawanan dengan menganiaya dan janganlah berperang atau terus berperang selama musuh telah menyerah. Hal ini sesuai dengan syarat keharusan yang dibahas oloeh para pakar fiqh kontemporer. Syarat kedua adalah syarat keseimbangan. Mencegah kezaliman itu sesuai dengan tindakan yang dilalukan oleh para musuh, tidak boleh melampaui atau menambah lebih dari tujuan tersebut. Fiqh Islam melarang tindakan-tindakan yang berwujud dendam secara kolektif terhadap mereka yang tidak berdosa sebagai tindak balas dendam terhadap pelanggaran individu baik pada peperangan biasa maupun pertikaian lokal. ${ }^{50}$

3. Berperang untuk mencegah kezaliman

Ajaran Islam memerintahkan orang-orang Islam dan negara Islam untuk menciptakan rasa saling tolong menolong dalam kebaikan dan takwa. Rasulullah saw telah mencontohkan dengan menolong sebagian kecil dari bangsa Quraisy setelah mereka meminta tolong kepada beliau dalam perjanjian Fudhûl. Atas dasar itu, fiqh Islam menegaskan bahwa pemberian pertolongan tersebut tidak terbatas pada orang-orang muslim saja, tetapi juga mencakup selain mereka. Jika yang meminta pertolongan kepada orang muslim adalah negara yang terzalimi, maka pertolongan tersebut menjadi wajib jika hal ini mengacu kepada perjanjian pertahanan kolektif. ${ }^{51}$

Atas dasar motif-motif di atas dapat diketahui bahwa tujuan berperang dalam Islam berporos pada manusia dalam upaya membebaskan dan mengeluarkannya dari kelemahan dan kezaliman dalam hidupnya. Peperangan bertujuan membebaskan kaum yang lemah dan mereka yang terjebak dalam berbagai macam perlakuan tidak kejahatan dan penyiksaan dari kesewenangwenangan dan caci makian. Dengan demikian, hal ini merupakan 
persoalan kemanusiaan secara universal dan bukan masalah kelompok Islam sendiri. Hal itu merupakan perlindungan kemanusiaan dari kejahatan dan pertumpahan darah. Sebab utama terjadinya perang adalah adanya serangan musuh terhadap wilayah Islam secara praktis dan negara Islam diperbolehkan ikut serta dalam peperangan bersenjata untuk melindungi saudarasaudaranya yang hidup di negara lain.

\section{Penutup}

Al-Qur'an membedakaan antara konsep qitâl dengan konsep jihad. Jihad menunjuk kepada suatu konsep yang lebih komprehensif, di mana salah satu sisinya adalah berjuang di jalan Allah swt melalui penggunaan senjata (qitâl). Jihad itu selalu baik, akan tetapi, qitâl adalah sesuatu yang berbeda sama sekali. Setiap acuan pada qitâl di dalam al-Qur'an selalu dibatasi oleh kondisi kondisi tertentu. Akan tetapi desakan pada jihad, seperti acuan pada kebenaran dan keadilan, selalu bersifat mutlak dan tidak bersyarat. Pada berbagai kesempatan ketika al-Qur'an mendesak umat Islam untuk berperang, al-Qur'an selalu mensyaratkan agar hal itu dilakukan tanpa perilaku melampaui batas, sesuai kepantasan disertai sikap memaafkan dan mencari perdamaian.Tak satu pun teks dalam al-Qur'an yang mengakui adanya gagasan tentang perang yang tidak terbatas.

Demi menjunjung tinggi kebenaran, Islam telah menetapkan batas-batas tertentu dalam perang. Islam melarang penyerangan terhadap orang-orang yang tidak ikut perang seperti anak-anak, perempuan, lansia, janda, pertapa, pendeta atau siapa pun yang tidak berusaha atau tidak bisa memerangi umat Islam. Pada setiap operasi militer, Nabi saw selalu melarang pasukannya melukai orang-orang yang tidak ikut berperang atau secara sia-sia merusak harta atau tumbuh-tumbuhan. Nabi saw justru memerintahkan untuk merawat mereka yang terluka atau memberi makan bagi yang membutuhkan, termasuk tawanan perang.

Meski Islam mengakui keabsahan perang dalam batas-batas tertentu, perang suci (al-harb al-muqaddasah) bukan ungkapan yang 
dipakai al-Qur'an atau para teolog muslim. Dalam teologi Islam, perang itu tak pernah suci. Apa pun pembenaran keagamaan dikemukakan orang muslim di masa lalu, istilah "perang suci" selalu membawa akibat mengerikan. Menghendaki suatu perang suci saat ini hanya berarti menyusuri suatu jalan buntu. Jika perang tersebut sah, maka mereka yang terbunuh di dalam peperangan dipandang sebagai syuhadâ' (martir). Akan tetapi penentuan status syahid ada pada wilayah eksklusif Tuhan; hanya Tuhan yang bisa menilai niat seseorang dan ketulusan niatnya, dan akhirnya Tuhanlah yang berhak menentukan apakah mereka layak menjadi syuhadâ' atau tidak.

Walaupun al-Qur'an tidak membenarkan gagasan tentang perang yang tak terbatas atau konsep perang suci, keadaan historis pada abad ke-9 dan ke-10 sangat mempengaruhi para ahli hukum dalam cara mereka membaca, menulis dan menafsirkan al-Qur'an. Pada periode sejarah ini, bangsa-bangsa dan dinasti-dinasti, karena tiadanya pakta perdamaian, memandang diri mereka selalu berada dalam situasi perang terus menerus dengan semua yang lain. Di abad pertengahan, menaklukkan dan mengalahkan pihak yang lemah adalah bagian dari kebiasaan dan praktik bangsa dan kerajaan yang diterima. Atas dasar, itu wajar kalau para ahli hukum merumuskan kondisi umat Islam sebagai selalu dalam situasi perang terus menerus dengan kelompok lain sehingga membagi dunia menjadi dua wilayah yaitu dâr al-Islâm dan dâr al-harb.

\section{Daftar Pustaka}

El-Fadl, Khaled Abou. Cita dan Fakta Toleransi Islam: Puritanisme versus Pluralisme. Bandung: Arasy Mizan, 2003. . Selamatkan Islam dari Muslim Puritan. Jakarta: Serambi, 2005.

Fithriyawan, Husni. "Jihad dalam perspektif Muhammad Fethullah Gulen", al-Jinayah. Volume 3 Nomor 1 Juni 2017.

Khairah, Muflikhatul. "Jihad dan Hukum Perang dalam Islam". Jurnal al-Qanun. Volume 11 Nomor 2 Desember 2008. 
Kimball, Charles. Kala Agama Jadi Bencana. Bandung: Mizan, 2003.

Shihab, Alwi. Islam Inklusif. Bandung: Mizan, 2008.

Shodiq, Muh. Fajar. "Perlindungan Penduduk Sipil dan Etika Perang dalam Islam". Gema. Tahun XXVI/48/Februari 2014-Juni 2014.

Widhiyoga, Ganjar. "Normativitas Perang dalam Islam". Jurnal Politik Profetik. Volume 2 Nomor 2 Tahun 2013.

Zemmali, Ameur (Editor), Islam dan Hukum Humaniter Internasional. Bandung: Mizan, 2012. 